DOI

\title{
ІННОВАЦІЙНІ МЕТОДИ ВИКЛАДАННЯ ДИСЦИПЛІН У МЕДСЕСТРИНСТВІ
}

\author{
С. О. Ястремська
}

ДВНЗ “Тернопільський державний медичний університет

імені І. Я. Горбачевського МОЗ України”

\section{INNOVATIVE TEACHING STRATEGIES IN NURSING EDUCATION}

\author{
S. O. Yastremska \\ SHEI “Ternopil State Medical University by I. Ya. Horbachevsky of MPH of Ukraine”
}

\begin{abstract}
У статті викладено актуальні питання використання інноваційних методик у навчальному процесі медичних сестер у вищому медичному навчальному закладі на сучасному етапі.

Наведена нова методика дебрифінгу, що є важливим компонентом клінічного моделювання. Застосування дидактичних підходів до клінічної освіти через метод дебрифінгу може належним чином допомогти в підготовці студентів до практичної діяльності через необхідність поєднувати основні знання з клінічною майстерністю.
\end{abstract}

The article presents topical issues of currently usage of innovative methods in education processe of nurses in higher medical educational establishments.

It provides a new method of debriefing, which is an important component of clinical simulation. An application of didactic approaches to clinical education through debriefing can help in adequately preparation of students to promote their practical activities because of the need to combine knowledges with basic clinical skills.

Вступ. Висока якість вищої освіти в Україні може бути забезпечена шляхом інтеграції фахових і педагогічних складових змісту, спрямованого на формування компетентного фахівця, здатного до неперервного навчання [1].

3 огляду на це, головним завданням професійної медсестринської освіти є підготовка кваліфікованих конкурентоспроможних кадрів з високим рівнем сформованості професійних знань, навичок і вмінь, творчого мислення, кращих людських якостей, національної свідомості.

В умовах науково-технічного прогресу постають певні вимоги до якості професійної підготовки медичних сестер: вільне володіння фундаментальними і спеціальними знаннями та вміннями у питаннях комплексного догляду за пацієнтами; здатність до аналітичного мислення і творчої діяльності, що пов' язана з функціональними обов'язками медичної сестри; здатність до самовдосконалення і самонавчання тощо [2].

Це потребує зусиль у наступних напрямах: поперше, удосконалення змісту системи знань з метою підвищення рівня професійних умінь медичних сестер; по-друге, застосування як у теоретичному,

(c) С. О. Ястремська так і в практичному навчанні спеціальних методичних прийомів, що спрямовані на використання отриманих знань у практичній підготовці. Ідеться про розробку, вдосконалення та впровадження у навчальний процес педагогічних інновацій, що розглядаються у світовій педагогіці як найбільш успішна альтернатива традиційним підходам у професійній підготовці фахівців [3].

Основна частина. Мета сучасної освіти - модернізувати систему освіти в університеті за рахунок впровадження елементів навчання, заснованих на формуванні базових компетенцій, що дозволяють випускникам самостійно здобувати знання, максимально наближені до практичної медицини, впровадити в навчальний процес систему інтерактивних методів навчання [4].

Опрацювання вітчизняної наукової літератури показало, що в теорії і практиці вищої освіти накопичено значний досвід, який може стати основою професійної підготовки майбутніх медичних сестер: окреслено методологічні основи неперервної професійної освіти (С. У. Гончаренко, І. А. Зязюн, В. Г. Кремень, Н. Г. Ничкало, С. О. Сисоєва); визначено загальнопедагогічні засади організації навчального процесу у вищій школі (А. М. Алексюк, А. Є. Мойсеюк, Н. Ф. Тализіна); здійснено аналіз 
проблеми якості професійної освіти (Е. Е. Карпова, М. І. Сметанський); досліджуються теоретичні і практичні основи професійного навчання (О. М. Леонтьєва, Є. О. Мілерян, К. К. Платонов), проблеми алгоритмізації практичної підготовки (В. П. Беспалько, Л. М. Ланда, В. О. Скакун та ін.).

Питання розвитку і модернізації вищої медичної освіти грунтовно розглянуті в наукових працях І. Є. Булах, Ю. В. Вороненка; шлях розвитку медсестринської освіти простежено в дослідженнях Л. І. Воронової, О. М. Гуменюк, С. А. Мухіної, М. Б. Шегедин та ін.; шляхи адаптації студентів до навчання в вищому медичному навчальному закладі обгрунтував у своїх дослідженнях Я. В. Цехмістер.

Значна частина публікацій присвячена аналізу інноваційних технологій і методів навчання, зокрема дослідження Р. Гуревич, А. Павленко і С. Стешенко та ін.

Проблемам впровадження інновацій в освіту приділила увагу I. Богданова [5]. Вона визначила напрямки такого впровадження: вдосконалення традиційного педагогічного процесу (модернізація, модифікація, раціоналізація), трансформація традиційного процесу (радикальні перетворення), комплексність видозмін (модернізація, модифікація, раціоналізація традиційної системи і її трансформація). Однак питання ефективного застосування інноваційних методів навчання залишається ще не достатньо вивченим.

До інноваційних методів навчання відносять методи активного навчання. Х. Майхнер [6] зазначає, що людина в процесі пасивного сприйняття запам'ятовує 10 \% того, що прочитала, $20 \%$ - того, що почула, 30 \% - того, що побачила, 50 \% побаченого та почутого, а за активного сприйняття в пам'яті зберігається 80 \% того, що говорять самі, і 90 \% того, що роблять або створюють самостійно. Інноваційні методи сприяють ефективнішому опануванню матеріалу, сприяють його розумінню і практичній самореалізації.

Засвоєння основ професійної майстерності формується у майбутніх медичних сестер при вивченні фундаментальних, загальноосвітніх і клінічних дисциплін. Проте безпосереднє формування професійної майстерності відбувається саме при вивченні клінічних дисциплін. При цьому дуже важливим $€$ формування умінь застосовувати знання з сестринської справи в процесі подальшого навчання та, особливо, у професійній діяльності, необхідно навчитися насамперед приймати ефек- тивні рішення і здійснювати їх, діючи практично в колективі, критично аналізувати свою діяльність, вести пошук можливих альтернатив [2].

Інноваційним педагогічним методом, який дозволяє досягнути вищезазначеної мети, є метод дебрифінгу.

Технологія дебрифінгу є різновидом зворотного зв'язку для аналізу підсумків спільної діяльності і визначення якості навчання. Дебрифінг є важливою стратегією викладання та навчання у сфері охорони здоров'я. Цей метод розширює можливості навчання і дозволяє студентам вчитися на своїх помилках [7]. Застосування дидактичних підходів до клінічної освіти через метод дебрифінгу може належним чином підготувати студентів до клінічної практики через необхідність поєднувати основні знання з клінічною майстерністю [8, 9].

Дебрифінг (англ. Debriefing - “витягування”, в даному випадку знань 3 учасників ігрової взаємодії) - це процес перегляду суджень або думок учасників інтерактивного навчання, а також обговорення і порівняння їх вирішення з можливими альтернативами.

Процес дебрифінгу побудований на взаємодії всіх студентів, включаючи викладача. Педагог частіше виступає лише в ролі організатора процесу навчання, лідера групи, фасилітатора, творця умов для ініціативи студентів [10].

Обговорюючи підсумки інтерактивного заняття, а отже, і якість навчання за допомогою дебрифінгу, викладач концентрує увагу студентів саме на рішеннях, які вони приймають, їх переваги та недоліки, можливих альтернативних варіантах, але не більше того. Мета педагога в дебрифінгу не визнавати твердження студентів лише як “вірні” або “невірні”, а максимально “витягувати” інформацію з аналізу ігрового заняття, націлювати учасників підійти до вирішення проблеми з різних точок зору і тим самим дати їм більше можливостей для самостійного вибору дій [11].

Дебрифінг реалізує наступні функції:

- вивести учасників заняття 3 розіграних або аналізованих ролей;

- внести ясність у події (на рівні фактів);

- усунути виниклі непорозуміння і виправити помилки;

- зняти напругу (тривогу, занепокоєння) в тих учасників, які перебувають у такому стані;

-виявити установки, почуття і зміни, що відбулися з учасниками в ході, наприклад, ситуаційнорольових ігор; 
- дати учасникам заняття можливість розвинути в собі здатність до самоспостереження і самоаналізу і продемонструвати їх;

- удосконалювати навички ведення включеного спостереження;

- співвіднести підсумковий результат з наперед поставленими цілями;

- проаналізувати, чому події відбувалися саме так, а не інакше;

- зробити висновки за підсумками аналізу поведінки і дій учасників;

- закріпити або відкоригувати засвоєння нової інформації;

- намітити нові теми для роздумів і підготовки до наступного заняття;

- встановити зв’язок з попередніми і наступними заняттями і т. д.

У процесі дебрифінгу учасники заняття отримують знання про практичний досвід один одного, тобто отримують можливість вчитися на помилках інших.

Викладач повинен неодмінно дати ясну оцінку, що відбувається, і висловити свою професійну думку. Це важливо для того, щоб студенти зрозуміли чого вони вже навчилися (що необхідно закріпити) і над чим слід попрацювати в подальшому (що коректувати) [2, 12].

3 методом дебрифінгу викладачі Навчальнонаукового інституту медсестринства ДВНЗ “Тернопільський державний медичний університет імені І. Я. Горбачевського МОЗ України” познайомились під час перебування в медичній школі Університету МакЮвена, Канада. Програма візиту передбачала відвідання клінічного симуляційного центру університету, який є найбільшим і найкраще обладнаним у Канаді. Він займає територію 2300 м² i призначений для відпрацювання практичних навичок і критичного мислення у студентів у реалістичному середовищі. Центр обладнаний високотехнологічними симуляторами-манекенами дорослих пацієнтів, новонароджених, дітей, жінокпороділь, віртуальними симуляторами, статичними тренажерами. Симуляційний центр складається з 8 лабораторій, серед яких: лабораторія догляду за хворими на дому, уніфікована лабораторія догляду за пацієнтом, лабораторія віртуального навчання, операційна, лабораторія мобільності та ін. Можливостями центру користуються не тільки студенти-медсестри Університету МакЮвена, а й студенти медики Університету Альберта, тут також відбувається навчання поліції Едмонтона та інших студентів, що навчаються на суміжних 3 медициною спеціальностях.

Процес дебрифінгу починається з того, що кожен студент отримує ситуаційну клінічну задачу - “легенду”, з метою засвоєння конкретної практичної навички. Відпрацювання цієї навички проводиться в максимально наближених до клініки умовах - в навчальній палаті зі всім необхідним обладнанням і на манекені-симуляторі, що активно реагує на кожну дію медичної сестри. Процес відпрацювання практичної навички записується двома відеокамерами з різних ракурсів, після чого кожен студент переглядає це відео самостійно і разом іншими студентами та з викладачем. Це дозволяє студентам поступово вийти 3 ігрової взаємодії, коли до учасників спочатку звертаються як до персонажів і тільки потім - як до студентів. Після цього починається обговорення кожного кроку виконання алгоритму практичної навички, підмічаються помилки, неточності, студенти радять один одному, як краще було б зробити, чого слід уникати. Відбувається плавний перехід від обговорення почуттів та емоцій, проявлених студентами в конкретних ролях, які вони виконували, до більш об’єктивного обговорення проблем. У процесі дебрифінгу учасники заняття отримують знання про практичний досвід один одного, тобто отримують можливість вчитися на помилках інших. Тому сесія дебрифінгу є найважливішою частиною заняття із застосуванням інтерактивних технологій. Саме при такому обговоренні прояснюється сенс зробленого, підводиться риска під завершенням теми і встановлюються інформаційні містки між відомими і новими знаннями, які знадобляться в майбутньому. Кожен раз, коли студенти зіставляють поставлені цілі і отриманий результат, вони освоюють місію менеджера, чия праця, як відомо, оцінюється за кінцевим результатом. Обговорюючи підсумки інтерактивного заняття, а отже, і якість навчання за допомогою дебрифінгу, викладач концентрує увагу студентів саме на рішеннях, які вони приймають, їх переваги та недоліки, наголошує на можливих альтернативних варіантах, але не більше того. Оцінити рішення як правильне або неправильне не завжди можливо (наприклад, у тренінгу або при аналізі ситуації), а іноді і недоцільно.

Висновки. Отже, використання інноваційних методик у навчальному процесі ВНЗ, зокрема при вивченні клінічних дисциплін, створює умови для ефективної самореалізації особистості кваліфікованого фахівця у галузі медсестринства. Значною 
мірою це залежить від педагогічної майстерності викладача, від прояву його толерантності в навчально-виховному процесі, який проводиться як діалог особистостей: викладача й студента, - у результаті чого суттєво покращується мотивація студентів до навчання.

Виходячи з того, що майбутня професійна діяльність медичної сестри пов'язана із засвоєнням

\section{Список літератури}

1. Кузьмінський А. І. Педагогіка вищої школи : навч. посіб. / А. І. Кузьмінський. - К. : Знання, 2005. - 486 с.

2. Кузіна Н. П. Шляхи активізації розумової діяльності та формування клінічного мислення у студентів / Н. П. Кузіна // Інноваційні технології як засіб активізації навчально-пізнавальної діяльності студентів : матеріали навч.-метод. конф. - Вашківці, 2010. - С. 24-25.

3. Вакуленко В. М. Види інновацій в освіті та їх класифікація / В. М. Вакуленко // Вісник Національної академії Державної прикордонної служби України. - 2010. С. 41-45.

4. Максименко С. Д. Педагогіка вищої медичної освіти : підручник / С. Д. Максименко, М. М. Філоненко. - К. : Центр учбової літератури, 2014. - 288 с.

5. Богданова I. М. Педагогічна інноватика : навч. посіб. / І. М. Богданова. - О. : ТЕС, 2000. - 148 с.

6. Майхнер Х. Е. Корпоративные тренинги / Х. Е. Майхнер. - М. : ЮНИТИ, 2002. - 354 с.

7. The role of debriefing in simulation-based learning / R. Fanning and D. Gaba // Simulation in Healthcare. - 2007. - Vol. 2 (1). - P. 115-125. значної кількості практичних умінь і навичок, а кожна її дія має виконуватися чітко і безпомилково (оскільки від цього залежить ефективність лікування, здоров’я, а іноді і життя пацієнта), метод дебрифінгу можна вважати досить вдалою педагогічною технологією навчально-професійної підготовки.

8. Student learning in clinical nursing education: perceptions of the relationship between assessment and learning / A. Tiwari, D. Lam, K. Yuen [et al.] // Nurse Education Today. - 2005. - Vol. 25. - P. 299-308.

9. FIRST2ACT: Educating nurses to identify patient deterioration - a theory-based model for best practice simulation education // Nurse Education Today / P. Buykx, L. Kinsman, T. Cooper [et al.]. - On line at http:// WWW.sciencedirect.com/science?_ob=ArticleURL\&_ udi=B6WNX-52K137S.

10. Основы менеджмента. Полное руководство по кейс-технологиям / [Панфилова А. П., Громова Л. А., Богачек И. А., Абчук В. А.] ; под ред. В. П. Соломина. - СПб., 2004. - 240 с.

11. Мухина С. А. Современные инновационные технологии обучения / С. А. Мухина, А. А. Соловьева. - М. : ГЭОТАР - Медиа, 2008. - 360 с.

12. Філоненко М. М. Психолого-педагогічна готовність викладача ВМНЗ в інноваційних умовах освіти / М. М. Філоненко // Гуманітарний вісник. - Дод. 1 до вип. 27, т. II (35) : Тематичний випуск “Вища освіта України у контексті інтеграції до європейського освітнього простору”. - К. : Гнозис, 2012. - С. 333-339. 